\title{
Sensitization of Calcitonin Gene-Related Peptide Receptors by Receptor Activity-Modifying Protein-1 in the Trigeminal Ganglion
}

\author{
Zhongming Zhang, ${ }^{1}$ Christina S. Winborn, ${ }^{2}$ Blanca Marquez de Prado, ${ }^{1}$ and Andrew F. Russo ${ }^{1,2}$ \\ ${ }^{1}$ Department of Molecular Physiology and Biophysics, and ${ }^{2}$ Genetics Program, University of Iowa, Iowa City, Iowa 52242
}

\begin{abstract}
The neuropeptide calcitonin gene-related peptide (CGRP) from the trigeminal ganglion has been established as a key player in the pathogenesis of migraine. In this study, we provide evidence that the responsiveness of neuronal CGRP receptors is strongly enhanced in vitro and in vivo by expression of human receptor activity-modifying protein-1 (hRAMP1), an obligatory subunit of the CGRP receptor. We first demonstrated that activation of CGRP receptors on cultured trigeminal ganglion neurons increased endogenous CGRP mRNA levels and promoter activity. The promoter activation was cAMP dependent and blocked by the antagonist BIBN4096BS [1-piperidinecarboxamide, $N$-[2-[[5-amino-L-[[4-(4-pyridinyl)-l-piperazinyl] carbonyl]pentyl]amino]-1-[(3,5-dibromo-4-hydroxyphenyl) methyl]-2-oxoethyl]-4-(1,4-dihydro-2-oxo-3(2H)-quinazolinyl)], a new antimigraine drug. Gene transfer using an adenoviral hRAMP1 expression vector increased the maximal production of cAMP by $1.8 \pm 0.2$-fold and decreased the $\mathrm{EC}_{50}$ to $2.3 \pm 0.8 \mathrm{~nm}$ from $9.0 \pm 5.9 \mathrm{nM}$ and $15.6 \pm 5.2 \mathrm{~nm}$ in uninfected and control-infected cultures, respectively. To establish whether RAMP1 is limiting in vivo as indicated from the culture studies, a transgenic mouse expressing hRAMP1 in the nervous system was generated. After CGRP injection into the whiskerpad, the hRAMP1 transgenic mice displayed $2.2 \pm 0.2$-fold greater plasma extravasation, which is a measure of neurogenic inflammation. These results demonstrate that RAMP1 is functionally rate limiting for CGRP receptor activity in the trigeminal ganglion, which raises the possibility that elevated RAMP1 might sensitize some individuals to CGRP actions in migraine.
\end{abstract}

Key words: migraine; CGRP; neurogenic inflammation; calcitonin; Cre-transgenic; cAMP; gene transfer; GPCR; transcription; transgenic; trigeminal

\section{Introduction}

There is increasing evidence that the neuropeptide calcitonin gene-related peptide (CGRP) from the trigeminal ganglion is a major player in migraine (Goadsby, 2005; Waeber and Moskowitz, 2005; Goadsby, 2006). CGRP levels are elevated during spontaneous and nitroglycerin-induced migraine (Goadsby et al., 1990; Gallai et al., 1995; Juhasz et al., 2003) and reduced by triptan antimigraine drugs (Goadsby et al., 2002). A causal role for CGRP in migraine has been revealed by induction of migrainelike headache after peripheral injection of CGRP (Lassen et al., 2002) and by the effectiveness of the CGRP receptor antagonist 1-piperidinecarboxamide, $N$-[2-[[5-amino-L-[[4-(4-pyridinyl)-1piperazinyl] carbonyl]pentyl] amino]-1-[(3,5-dibromo-4-hydroxyphenyl)methyl]-2-oxoethyl]-4-(1,4-dihydro-2-oxo-3(2H)-

\footnotetext{
Received 0ct. 19, 2006; revised Jan. 24, 2007; accepted Jan. 24, 2007.

This work was supported by National Institutes of Health (NIH) Grants DE016511 and HL14388. The University of lowa Gene Transfer Vector Core and Transgenic Animal Facility are supported in part by the NIH and Roy J. Carver Foundation. We thank Penny Dong, David Infanger, Amy Jongeling, and Tom W. Schmidt for assistance; Donna Hammond for advice on the inflammation assay; Baoli Yang for advice and the nestin-cre mice; lan Dickerson and Kevin Oliver for antibodies; Gary Owens for suggesting the cre strategy and the CX1-GFP vector; Henri Doods for BIBN4096BS; Maria Scheel and Beverly Davidson for generating the adenoviral vectors; and Norma Sinclair, Trish Yarolem, Joanne Schwarting, and Curt Sigmund for generating transgenic mice.

Correspondence should be addressed to Andrew F. Russo, Department of Molecular Physiology and Biophysics, University of lowa, lowa City, IA 52242. E-mail: andrew-russo@uiowa.edu.

D0I:10.1523/JNEUROSCI.4542-06.2007

Copyright $\odot 2007$ Society for Neuroscience $\quad$ 0270-6474/07/272693-11\$15.00/0
}

quinazolinyl) (BIBN4096BS) as an antimigraine drug (Olesen et al., 2004).

CGRP actions are mediated by an unusual G-protein-coupled receptor. The functional receptor consists of the seventransmembrane calcitonin-like receptor (CLR) and two requisite subunits, receptor activity-modifying protein-1 (RAMP1) and receptor component protein (RCP) (Poyner et al., 2002). RAMP1 is a small single-transmembrane protein that is required for CGRP binding to CLR (McLatchie et al., 1998). Interaction of CLR with two other RAMP proteins, RAMP2 or RAMP3, yields adrenomedullin receptors (Hay et al., 2006b). RCP is an intracellular protein that interacts with CLR and facilitates cAMP production (Evans et al., 2000). A second, less prevalent CGRP receptor has been suggested, although its molecular identity remains unclear (Poyner et al., 2002). The CGRP receptor can activate multiple signal transduction pathways, although it is most commonly coupled to Gs $\alpha$ to increase cAMP levels (Poyner et al., 2002; Brain and Grant, 2004).

There are multiple sites of CGRP action that may be relevant during migraine (Durham, 2004). First, CGRP receptors are located on the cerebrovasculature, where they cause vessel relaxation that can be blocked by BIBN4096BS (Edvinsson et al., 2002; Moreno et al., 2002; Oliver et al., 2002). Second, CGRP receptors are present on dural mast cells, from which CGRP can release cytokines and inflammatory agents during neurogenic inflam- 
mation (Theoharides et al., 2005). Third, there are postsynaptic CGRP receptors on second-order sensory neurons within brainstem trigeminal nuclei that can also be inhibited by BIBN4096BS (Storer et al., 2004; Fischer et al., 2005; Levy et al., 2005).

In this report, we have studied the CGRP receptors in the trigeminal ganglion, which may be a fourth site that is relevant for CGRP and BIBN4096BS actions in migraine. Our findings are in agreement with a recent report of functional CGRP receptors (Fabbretti et al., 2006) and the presence of CLR RNA and RCP immunostaining in trigeminal ganglia (Edvinsson et al., 1997; Moreno et al., 1999; Ma et al., 2003). Importantly, we demonstrate that elevation of RAMP1 increases neuronal CGRP receptor activity in cultured neurons and increases CGRP-induced subcutaneous inflammation in transgenic mice. Based on these findings, we propose that RAMP1 is functionally rate limiting for CGRP actions in the trigeminovasculature system.

\section{Materials and Methods}

Primary cultures. Trigeminal ganglia were cultured from 2- to 4-d-old Sprague Dawley rats as described previously (Durham et al., 2004). Trigeminal ganglia were isolated, washed in $10 \mathrm{ml}$ of cold plating medium (25 mм HEPES, pH 7.2-7.4, Leibovitz L-15 medium; Invitrogen, Grand Island, NY) and collected by centrifugation. The ganglia were resuspended in $10 \mathrm{ml}$ of plating medium containing $10 \mathrm{mg} / \mathrm{ml}$ dispase II (Invitrogen) and $1 \mathrm{U} / \mathrm{ml}$ RQ1 DNase (Promega, Madison, WI), incubated for $30 \mathrm{~min}$ at $37^{\circ} \mathrm{C}$ with gentle shaking, and further dissociated by triturating through a $5 \mathrm{ml}$ pipette until the medium was cloudy. Neuronal cells were enriched by density centrifugation in a bovine serum albumin (BSA) gradient and plated at a density of approximately four ganglia per $25 \mathrm{~mm}$ circular coverslip [previously coated with $200 \mu \mathrm{l} \mathrm{of} 4 \mu \mathrm{g} / \mathrm{ml}$

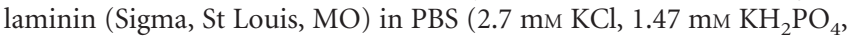
$\left.137 \mathrm{~mm} \mathrm{NaCl}, 4.3 \mathrm{~mm} \mathrm{Na}_{2} \mathrm{HPO}_{4}\right)$ ]. Cells were incubated overnight in trigeminal ganglia (TG) medium [L-15 with $10 \%$ fetal bovine serum (FBS); Invitrogen], $50 \mathrm{~mm}$ glucose, $250 \mu \mathrm{M}$ ascorbic acid, $8 \mu \mathrm{M}$ glutathione, $2 \mathrm{~mm}$ glutamine, $10 \mathrm{ng} / \mathrm{ml}$ mouse $2.5 \mathrm{~S}$ nerve growth factor (NGF; Alomone Labs, Jerusalem, Israel), $100 \mathrm{U} / \mathrm{ml}$ penicillin, $100 \mu \mathrm{l} / \mathrm{ml}$ streptomycin) at $37^{\circ} \mathrm{C}$ and ambient $\mathrm{CO}_{2}$. Treatments were performed the next day unless otherwise specified.

Reverse transcription-PCR. For identifying the CGRP receptor RNAs in primary cultures of trigeminal ganglia, RNA was isolated using TRIzol reagent (Invitrogen). RNA quality was confirmed by agarose gel electrophoresis. Reverse transcription (RT) was performed using $0.5 \mu \mathrm{g}$ of RNA, $1 \times$ first-strand reverse transcription buffer (Promega), $10 \mathrm{~mm}$ DTT, $2.5 \mathrm{~mm}$ dNTP, $1 \mu \mathrm{M}$ antisense primer, $20 \mathrm{U}$ of Rnasin (Promega), and $5 \mathrm{U}$ of AMV reverse transcriptase (Promega) in a $10 \mu \mathrm{l}$ reaction at $42^{\circ} \mathrm{C}$ for $1 \mathrm{~h}$. PCR was performed using $1 \mu \mathrm{l}$ of the RT product with primers complementary to rat CLR, RAMP1, or RCP for 30 cycles. Cycle conditions were $0.5 \mathrm{~min}$ at $94^{\circ} \mathrm{C}, 1 \mathrm{~min}$ at $55^{\circ} \mathrm{C}$ for RCP and RAMP 1 , and $60^{\circ} \mathrm{C}$ for CLR, $1 \mathrm{~min}$ at $72^{\circ} \mathrm{C}$. PCR products were gel purified and cloned into pGEM-T easy vector (Promega) and verified by DNA sequencing. Primer sequences were as follows: RCP (GenBank\#AF440799) upstream base 31 5'CGAACGCTGCCCTGCTC3', downstream base 434 5'CGCGTCATTGCTAGTGCTTTTG3'; CLR (GenBank \#X70658) upstream base 786 5'TAACAACAGCACGCATGAGAAAGT3', downstream base 1190 5'AACCCCCAGCCAAGAAAATAATAC3'; RAMP1 (GenBank \#NM031645) upstream base 113 5'CTGCCTGCCGGGACCCTGACTATG3', downstream base 479 5'ATGCCCTCTGTGCGCTTGCTCCTC3'.

For CGRP quantitative real-time PCR (Q-PCR) assays, RNA was isolated from primary cultures treated with $100 \mathrm{nM}$ rat CGRP (dissolved in PBS; Sigma), $10 \mu \mathrm{M}$ forskolin (100 mm stock dissolved in 95\% ethanol; Sigma) or PBS vehicle for $4 \mathrm{~h}$ in TG medium without NGF. RNA $(1 \mu \mathrm{g})$ was reverse transcribed with random hexamers using the reagents in the Taqman RT-PCR mix (Applied Biosystems, Foster City, CA) in a total reaction volume of $10 \mu$ l. The reverse transcription reaction product (50 ng) was incubated with $50 \mathrm{~nm}$ primers for $\beta$-actin or CGRP in the SYBR green master mix (Applied Biosystems) in $50 \mu$ l. Reactions were per- formed in triplicate, analyzed on an Applied Biosystems PRISM 7700 thermocycler and quantitated with a relative standard curve using RNA from the neuronal-like cell line CA77 as calibrator RNA. PCR cycle conditions were $50^{\circ} \mathrm{C}$ for $2 \mathrm{~min}$ and $95^{\circ} \mathrm{C}$ for $10 \mathrm{~min}$, followed by 40 cycles of $95^{\circ} \mathrm{C}$ for $15 \mathrm{~s}$ and annealing/extension at $60.7^{\circ} \mathrm{C}$ for $1 \mathrm{~min}$. At the end of amplification, a thermal melt curve was generated, and the samples were analyzed by gel electrophoresis to confirm amplification of a single distinct product. CGRP (GenBank \#M11597) primers were as follows: upstream base 95 5'AACCTTAGAAAGCAGCCCAGGCATG3' and downstream base 340 5'GTGGGCACAAAGTTGTCCTTCACCA3'. $\beta$-actin (GenBank \#NM031144) primers were as follows: upstream base 812 5'ACGGTCAGGTCATCACTATGG3' and downstream base 1111 5'AGCCACCAATCCACACAG3'.

For RT-PCR detection of human RAMP1 (hRAMP1) expression in mouse tissues, total RNA was isolated with Trizol reagent and treated with DNase I, Amp Grade (Invitrogen). RNA concentration and purity were determined by spectrometry and checked by agarose gel electrophoresis. RNA was converted to cDNA using random hexamer primers as described above. PCR conditions were the same as those used for genotyping described below except that primers specific for hRAMP1 were used: upstream 5'CCAGGAGGCTAACTACGGTG3' and downstream 5'CTCCTGAAGTAGCGGCCA3', to yield a 228 bp product. Mouse glyceraldehyde 3-phosphate dehydrogenase (GAPDH) (GenBank \#NM001001303) was amplified as a control for RNA integrity using primers: upstream 5'ACCACAGTCCATGCCATCAC3' and downstream 5'TCCACCACCCTGTTGCTGTA3' (452 bp product). PCR products were confirmed by DNA sequence.

For Q-PCR assays of mouse RAMP1 (mRAMP1) and hRAMP1, total RNA was isolated from tissues using the RNeasy mini kit with on-column DNase I digestion (Qiagen, Valencia, CA). Total RNA $(1 \mu \mathrm{g})$ was reverse transcribed using random hexamers and the Taqman RT-PCR mix as described above. Q-PCR was performed using $50 \mathrm{ng}$ of cDNA, $600 \mathrm{nM}$ each primer, $0.025 \mathrm{U}$ of AmpliTaq Gold polymerase (Applied Biosystems), $1 \times$ AmpliTaq Gold Buffer, $3 \mathrm{~mm} \mathrm{MgCl}_{2}, 550 \mu \mathrm{m}$ each dNTP, $5 \%$ dimethylsulfoxide (DMSO), 0.005\% SYBR Green (Invitrogen), and 0.1 $\mu \mathrm{M}$ fluorescein (EMD Biosciences, La Jolla, CA) in $15 \mu \mathrm{l}$. The cycle conditions were as follows: $50^{\circ} \mathrm{C}$ for $2 \mathrm{~min}, 95^{\circ} \mathrm{C}$ for $10 \mathrm{~min}$, followed by 40 cycles of $95^{\circ} \mathrm{C}$ for $15 \mathrm{~s}$ and annealing/extension at $60^{\circ} \mathrm{C}$ for $30 \mathrm{~s}$ and $72^{\circ} \mathrm{C}$ for $45 \mathrm{~s}$. Reactions were performed in duplicate and analyzed using a Bio-Rad (Hercules, CA) MY-IQ thermocycler. At the end of amplification, a thermal melt curve was generated. Samples that did not yield a homogenous curve were not included. The mRAMP1 and hRAMP1 Ct values were converted to absolute copy numbers using standard curves generated with 1:10 serial dilutions of pGEM-QmRAMP1 and pbsCX1LEL-hRAMP1 plasmids in $10 \mathrm{ng} / \mathrm{ml}$ yeast tRNA. pGEM-QmRAMP1 was constructed by amplifying brain mRAMP1 cDNA using the Q-PCR primers and inserted into PGEM-T-easy. mRAMP1 primers were as follows: upstream 5'CGGGACCCTGACTATGGGA3' and downstream 5'GCACCTGCTGAAGTAATCGATGG3' (231 bp product). hRAMP1 primers were: upstream 5'CCTCACCCAGTTCCAGGTAG3' and downstream 5'CTCCTGAAGTAGCGGCCA3' (189 bp product). Mouse GAPDH primers described above were used as a control. Mouse RAMP2 and 3 were amplified under the same conditions as mRAMP1, although absolute levels were not measured. Mouse RAMP2 (GenBank \#NM019444) primers were: upstream 5'AGCAAACACATGTCCTACCTTGCTG3' and downstream 5'TCGCAAAGTGTATCAGGTGAGCCT3' (207 bp product). Mouse RAMP3 (GenBank \#NM019511) primers were: upstream 5'TATGCGGCTGCAACGAGACA3' and downstream 5'ACTGCCTGTGGATTCCAGTGATGA3' (225 bp product).

Immunocytochemistry. For CGRP receptor protein immunostaining, cultures were briefly rinsed in PBS and fixed in $4 \%$ paraformaldehyde in PBS for $30 \mathrm{~min}$ at $4^{\circ} \mathrm{C}$. Cells were washed twice with PBS and permeabilized with $0.3 \%$ Triton X-100 (diluted in PBS) for 45 min at room temperature. Blocking was done in PBS with $10 \%$ BSA for $1 \mathrm{~h}$ at room temperature. Cells were incubated with anti- $\beta$-tubulin III mouse antibody (Sigma) diluted 1:500 and either CLR chicken antiserum OCA-910 (Oliver et al., 2002) diluted 1:100, RAMP-1 rabbit antiserum OA-350 (Evans et al., 2000; Oliver et al., 2002) diluted 1:200, or RCP rabbit 
antiserum R83 (Evans et al., 2000) diluted 1:200 in PBS, 10\% FBS, and incubated overnight at $4^{\circ} \mathrm{C}$. CLR and RAMP 1 antisera were provided by K. Oliver (Merck Sharp and Dohme Neuroscience Research Center, Harlow, Essex, UK). RCP antiserum was provided by I. Dickerson (University of Rochester, Rochester, NY). Cells were washed and blocked for an additional $30 \mathrm{~min}$ before incubation for $1-1.5 \mathrm{~h}$ at room temperature with secondary antibodies (all diluted 1:200): rhodamine-conjugated rabbit anti-chicken (Chemicon International, Temecula, CA), rhodamine-conjugated donkey or goat anti-rabbit (The Jackson Laboratory, Bar Harbor, ME), FITC-conjugated sheep anti-mouse (The Jackson Laboratory), or FITC-conjugated donkey anti-mouse (The Jackson Laboratory). Nuclei were labeled with To-pro3 (Invitrogen, Eugene, OR), diluted 1:1000 in DMSO. Images were captured using a Zeiss LSM 510 confocal microscope.

Adenoviral vectors and infections. The $1.25 \mathrm{~kb}$ rat CGRP promoter (Durham and Russo, 2003) and firefly luciferase gene was removed from pGL3 as a KpnI and XbaI digestion fragment and inserted into the shuttle plasmid pacAd5 K-N pA. Human RAMP1 cDNA, provided by Steve Foord (GlaxoSmithKline, Research Triangle Park, NC), was cloned into pacAd5 cytomegalovirus (CMV)-K-N pA as described previously (Zhang et al., 2006). The shuttle plasmid pacAd5 CMV-K-N pA with enhanced green fluorescent protein (GFP) was used to generate a control virus. The University of Iowa Gene Transfer Vector Core generated the replication-deficient recombinant adenoviruses (serotype 5) Ad rCGRPLuc, Ad CMV-hRAMP1, and Ad CMV-GFP. Adenovirus titers were determined by plaque assays on 293 cells. The purified viruses were aliquoted in PBS with $3 \%$ sucrose and stored at $-80^{\circ} \mathrm{C}$. Cells were infected with $2 \mu \mathrm{l}$ of virus $\left(1 \times 10^{10} \mathrm{pfu} / \mathrm{ml}\right.$ for Ad rCGRP-Luc, $7.2 \times 10^{10} \mathrm{pfu} / \mathrm{ml}$ for Ad CMV-hRAMP1, and 2-5 $\times 10^{10} \mathrm{pfu} / \mathrm{ml}$ for Ad CMV-GFP) for $4 \mathrm{~h}$ in $1 \mathrm{ml}$ of serum- and NGF-free TG medium at $37^{\circ} \mathrm{C}$, ambient $\mathrm{CO}_{2}$. Cells were grown overnight in $2 \mathrm{ml}$ of TG medium before luciferase and cAMP assays. Viability after infections was estimated to be $>95 \%$ based on exclusion of trypan blue dye (1:1 dilution, 3 min incubation; Invitrogen). Viability was not affected by infection with any of the viral vectors.

Bioluminescence imaging and luciferase assays. Bioluminescence imaging was performed using the Xenogen IVIS 100 charged coupled device (CCD) camera with Igor Pro 4.2 living image software (Xenogen, Alameda, CA). Cells were infected with Ad rCGRP-Luc as described above and incubated overnight. Cells were given fresh NGF-free TG medium and incubated an additional $2 \mathrm{~h}$ before prestimulus luciferase activity was measured. Luciferin (0.25 mm; Xenogen) was added to each well, and luciferase activity was measured for $3 \mathrm{~min}$ and reported as photons per second per steradian per centimeter squared. The relative light production was assigned a false color, and images were overlaid onto the black and white image of the plates. Data were collected from the entire $25 \mathrm{~mm}$ diameter coverslip within the $35 \mathrm{~mm}$ culture dish well. The background was not subtracted. In initial studies, backgrounds from either cell-free wells or mock-infected cells were only $\sim 100$ photons per second per steradian per centimeter squared.

Cultures were treated with either $100 \mathrm{~nm}$ rat CGRP, the combination of $100 \mathrm{~nm}$ CGRP and $500 \mathrm{~nm} \mathrm{CGRP}_{8-37}$, or $10 \mu \mathrm{m}$ forskolin. When indicated, cells were pretreated for 20 min with either $10 \mu \mathrm{M} \mathrm{H} 89$ in DMSO (Sigma), 10 nм BIBN4096BS in $\mathrm{H}_{2} \mathrm{O}$ (provided by H. Doods, Boehringer Ingelheim, Ingelheim, Germany), 30 min with $25 \mu \mathrm{M}$ 8-bromoadenosine 3',5'-cyclic monophosphorothioate, Rp-isomer (8Br-Rp-cAMPS; Alexis Biochemicals, San Diego, CA), or the appropriate amount of vehicle. Cells were incubated for an additional $4 \mathrm{~h}$, and poststimulus luciferase activity was measured. Data were reported as fold change in luciferase activity between poststimulus and prestimulus readings. Conditions were performed in duplicate unless otherwise noted.

Luciferase activity was also measured by an MLX microplate luminometer with Revolution 4.25 software (Dynex Technologies, Chantilly, VA) using a luciferase assay kit (Promega). Cells were treated with the drugs described above for $4 \mathrm{~h}$, washed in PBS, and scraped in $100 \mu \mathrm{l}$ of lysis buffer (Promega). Luciferase activity was reported as either mean light units or fold change normalized to vehicle. Experiments were performed in duplicate and repeated three to four times as indicated. Statistical analysis was performed using ANOVA followed by Tukey's test (two-tailed) using SPSS (Chicago, IL) software and considered significant at $p<0.05$.

cAMP, CGRP, and substance $P$ radioimmunoassays. Intracellular cAMP levels were measured by radioimmunoassays using the overnight protocol (GE Healthcare, Arlington Heights, IL). Cells were washed with serum- and NGF-free TG medium twice and incubated in the same medium containing $0.25 \mathrm{mg} / \mathrm{ml} 3$-isobutyl-1-methylxanthine (Sigma) for $15 \mathrm{~min}$. For testing the effect of hRAMP1, cultures were infected for $24 \mathrm{~h}$ with $2 \mu \mathrm{l}$ of RAMP1 virus, or an equal amount of the control GFP virus applied to each well on the day after plating. The samples were then treated for $10 \mathrm{~min}$ with the indicated concentration of rat CGRP, $10 \mu \mathrm{M}$ forskolin, or a combination of $100 \mathrm{~nm}$ CGRP and human $500 \mathrm{~nm}$ $\mathrm{CGRP}_{8-37}$ (Sigma) or PBS vehicle. Reactions were stopped by aspirating the medium and adding $1 \mathrm{ml}$ of ice-cold $0.5 \mathrm{~N}$ perchloric acid containing $180 \mu \mathrm{g} / \mathrm{ml}$ theophylline (Sigma). The extractions were moved into glass tubes and neutralized by adding $500 \mu \mathrm{l}$ of $0.72 \mathrm{M} \mathrm{KOH} / 0.6 \mathrm{M} \mathrm{KHCO}_{3}$ for $10 \mathrm{~min}$ at room temperature. Samples were centrifuged at $3000 \times \mathrm{g}$ for 10 $\min$ at $4^{\circ} \mathrm{C}$. Supernatants were stored at $-20^{\circ} \mathrm{C}$. Each experimental condition was performed in duplicate and repeated at least three times. Data were fitted to a sigmoidal curve to obtain the maximum response, Hill coefficient, and $\mathrm{EC}_{50}$ using the Prism 3.0 software (GraphPad Software, San Diego, CA). $\mathrm{EC}_{50}$ values were calculated using a nonlinear regression analysis with the formula (effect $=$ maximum response $/ 1+\mathrm{EC}_{50} /$ agonist concentration). The data were statistically analyzed using ANOVA followed by Tukey's test (two-tailed) using SPSS software and considered significant at $p<0.05$.

CGRP radioimmunoassays were performed as recommended (Peninsula Laboratories, San Carlos, CA) (Durham and Russo, 1999). Cultures were washed twice with HEPES-buffered saline (HBS) (22.5 mM HEPES, $135 \mathrm{~mm} \mathrm{NaCl}, 3.5 \mathrm{~mm} \mathrm{KCl}, 1 \mathrm{~mm} \mathrm{MgCl}_{2}, 2.5 \mathrm{~mm} \mathrm{CaCl}_{2}, 3.3 \mathrm{~mm}$ glucose, and $0.1 \%$ BSA, pH 7.4) for $15 \mathrm{~min}$. Cells were then incubated in HBS for $1 \mathrm{~h}$, and media were collected as the prestimulus sample. Cells were washed twice with HBS for $15 \mathrm{~min}$ and treated for $1 \mathrm{~h}$ with either $10 \mu \mathrm{M}$ forskolin or vehicle (ethanol), and then collected. Samples were dried under vacuum and dissolved in $150 \mu \mathrm{l}$ of radioimmunoassay buffer provided by the manufacturer.

Substance P radioimmunoassays were performed as recommended (Peninsula Laboratories). Twenty-four hours after infection with viral vectors, cells were washed once and then incubated for $30 \mathrm{~min}$ at $37^{\circ} \mathrm{C}$ with $1 \mathrm{ml}$ of $\mathrm{HBS}$ and mammalian protease inhibitor mixture (1:200 dilution; Sigma). After this acclimation period, the medium was replaced with $1 \mathrm{ml}$ of HBS with protease inhibitors for $1 \mathrm{~h}$ and then collected as the prestimulus sample. One milliliter of HBS with $1 \mu \mathrm{l}$ of PBS (vehicle), 10 $\mu \mathrm{M}$ forskolin, or CGRP ( 5 or $100 \mathrm{nM}$ ) was added for a $1 \mathrm{~h}$ incubation and then collected. Samples were dried under vacuum and dissolved in $200 \mu \mathrm{l}$ of radioimmunoassay buffer provided by the manufacturer. Statistical significance was measured by paired $t$ tests.

Generation of nestin/hRAMP1 transgenic mice. The hRAMP1 cDNA was subcloned from the pacAd5 CMV-hRAMP1 shuttle vector (Zhang et al., 2006). To facilitate the cloning, a second SV40 polyA sequence (GenBank \#NC001669) was first PCR amplified with addition of 5' XbaI and $3^{\prime}$ NotI sites and inserted downstream of the hRAMP1 cDNA in the shuttle vector. The hRAMP1 and SV40 polyA fragment was then cloned into HindIII and NotI sites of the pbsCX1-LEL expression vector provided by G. Owens (University of Virginia, Charlottesville, VA) (Okabe et al., 1997; Dikalova et al., 2005) to generate pbsCX1-LEL-hRAMP1. This vector has the CX1 promoter followed by the GFP gene flanked by loxP sites. CX1 is a hybrid of the chicken $\beta$-actin promoter and CMV enhancer. The vector also contains a $\beta$-actin intron and bovine globin polyadenylation signal. The transgene portion was gel purified and microinjected into one-cell C57BL/6J $\times$ SJL/J (B6SJL) fertilized eggs by the University of Iowa Transgenic Animal Facility. Six founder mice were identified by PCR amplification of genomic DNA purified from tail biopsies using an upstream hRAMP1 primer 5' GTTCTTCCTGGCAGTGCATG3' and downstream SV40 primer 5'TCCCCCTGAACCTGAAACATA3'. PCR was performed at $94^{\circ} \mathrm{C}(2 \mathrm{~min})$ for 1 cycle, followed by 35 cycles at $94^{\circ} \mathrm{C}(30 \mathrm{~s}), 62^{\circ} \mathrm{C}(1 \mathrm{~min}), 72^{\circ} \mathrm{C}(2 \mathrm{~min})$, and then 1 cycle at $72^{\circ} \mathrm{C}$ (8 $\mathrm{min})$.

Transgenic founders were backcrossed with C57BL/6J mice to gener- 
ate heterozygous GFP-hRAMP1 transgenic mice. The F1 progeny were screened to select the line with the most ubiquitous GFP fluorescence (strain 28412/3). Females were crossed with male nestin-cre mice [B6.Cg- $\mathrm{Tg}$ (Nescre) $1 \mathrm{Kln} / \mathrm{J}$; stock number 003771; The Jackson Laboratory] to produce double-transgenic mice. Double-transgenic mice were identified using the primers and conditions described above and cre primers: upstream 5'TGATGAGGTTCGCAAGAACC3' and downstream 5'CCATGAGTGAACGAACCTGG3'.

Western blots. Tissues were homogenized in PTN50 (50 mм PBS, 1\% Triton X-100, 50 mm $\mathrm{NaCl})$ plus $2 \%$ Protease Inhibitor Cocktail (Sigma) using a Tissumizer (Tekmar, Cincinnati, $\mathrm{OH})$. Protein was measured by Bradford assay (Bio-Rad). Lysates $(20 \mu \mathrm{g})$ were resolved by $12.5 \%$ SDS-PAGE and transferred to Immobilon-P membranes as recommended (Millipore, Bedford, MA). Membranes were incubated for $3 \mathrm{~h}$ with anti-RAMP1 (NY1020), anti-CLR (NY1045), or anti-RCP (R83) antiserum diluted 1:1000 in PBS containing 0.04\% Tween 20 (PBST) plus 1\% nonfat dry milk. NY1020 is a rabbit polyclonal antibody raised against a synthetic peptide from mouse RAMP1 (Zhang et al., 2006). NY1045 is a rabbit polyclonal antibody raised against a synthetic peptide from mouse CLR (Zhang et al., 2006). R83 is a rabbit antibody against RCP (Evans et al., 2000). After washing with PBST, the membranes were incubated with horseradish peroxidase-conjugated donkey anti-rabbit IgG (GE Healthcare) diluted 1:5000 in PBST. After thorough washing with PBST, immunocomplexes were visualized using enhanced chemiluminescence detection (GE Healthcare). The same filters were blocked with PBST plus 5\% nonfat dry milk for $1 \mathrm{~h}$ before incubating with GAPDH (V-18) goat polyclonal IgG (diluted 1:1000; Santa Cruz Biotechnology, Santa Cruz, CA) for $3 \mathrm{~h}$. Membranes were washed and then incubated with horseradish peroxidaseconjugated secondary antibodies for $30 \mathrm{~min}$ (donkey anti-goat IgG, diluted 1:10,000; Santa Cruz Biotechnology). For one experiment, the same filter was washed and reused for sequential hybridizations with RAMP1, CLR, and RCP.

Plasma extravasation assay. All animal procedures were approved by the University of Iowa Animal Care and Use Committee. Evans blue dye was injected and extracted from the plasma and skin samples as described previously (John et al., 1998). $10 \mathrm{mg} / \mathrm{kg}$ Evans blue in PBS was injected intravenously into the tail veins of male and female mice, 3-6 months of age. Mice were anesthetized after $5 \mathrm{~min}(72 / 13 \mathrm{mg} / \mathrm{kg}$, i.p., ketamine/ xylazine). In some experiments, the dye was intracardially injected into anesthetized mice. $20 \mu \mathrm{l}$ of $250 \mathrm{~nm}$ CGRP (5 pmol) or $20 \mu \mathrm{l}$ of PBS was subcutaneously injected into the anesthetized mice at the whiskerpad, lip region, or paw. After $20 \mathrm{~min}$, a $0.5 \mathrm{ml}$ blood sample was obtained by cardiac puncture and placed into EDTA collection tubes. The mice were killed by $\mathrm{CO}_{2}$ asphyxiation, and the skin and subcutaneous tissue surrounding the injection site were excised, weighed, minced, and placed into a mixture of acetone and $0.5 \%$ sodium sulfate ( $10 \mathrm{ml} / \mathrm{g}$ tissue). The tissue was homogenized for $90 \mathrm{~s}$ using a Tissumizer. The homogenate was incubated overnight at room temperature and then centrifuged at $3000 \times g$ for $10 \mathrm{~min}$. The supernatant was removed into a fresh tube and centrifuged at $10,000 \times g$ for $10 \mathrm{~min}$. The blood sample was centrifuged at $3000 \times g$ for $30 \mathrm{~min}$, and the plasma was stored at $-20^{\circ} \mathrm{C}$ until analysis. The dye content in the plasma and the tissue supernatants was determined in duplicates by absorbance at $620 \mathrm{~nm}$. The acetone/sodium sulfate mixture served as the blank and solvent for the standard curve, which
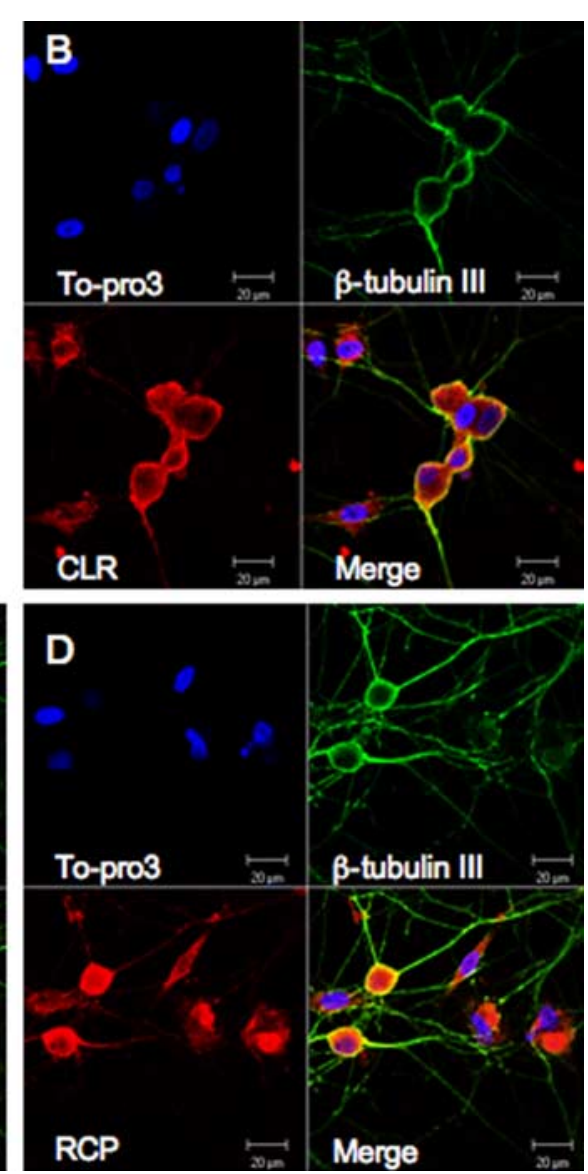

Figure 1. Identification of CLR, RAMP1, and RCP in cultured trigeminal ganglion neurons. $A$, Schematic and RT-PCR products of the CGRP receptor proteins $C L R, R A M P 1$, and RCP. RT-PCR products were resolved on an agarose gel and detected by ethidium immunocytochemical detection of $C L R(B)$, RAMP1 $(\boldsymbol{C})$, and RCP (D). The cultures were costained with neuronal marker $\beta$-tubulin III antibodies and the nuclear dye To-pro3. Individual and merged images are shown. Scale bars, $20 \mu \mathrm{m}$.

was linear from 0.25 to $20 \mu \mathrm{g} / \mathrm{ml}$ Evans blue. The total amount of Evans blue was expressed as the volume of exudate per weight of tissue as described previously (John et al., 1998). Two-way ANOVA followed by paired $t$ test was used to compare the effect of CGRP in the doubletransgenic mice and single-transgenic GFP-hRAMP1 mice.

\section{Results}

Identification of CLR, RAMP1, and RCP in cultured trigeminal ganglion neurons

The functional CGRP receptor is composed of three proteins: CLR, RAMP1, and RCP (Fig. $1 A$ ). The presence of CLR, RAMP1, and RCP RNA in cultured rat trigeminal ganglia was demonstrated by RT-PCR with sequence confirmation (Fig. 1A). To establish whether there was neuronal expression of the CGRP receptor proteins, double staining with neuron-specific $\beta$-tubulin III was performed (Fig. $1 B-D$ ). Immunocytochemical staining was observed for CLR, RAMP1, and RCP in all cells, although the signals consistently appeared greater in neurons than non-neuronal cells (presumed to be fibroblasts and satellite glia). Glial expression is in agreement with the finding of CLR and functional CGRP receptors in cultured astroglia (Moreno et al., 1999). The CLR-immunoreactive material was predominantly near the cell surface but also present in the cytoplasm. The RAMP1 and RCP signals were apparently distributed throughout the cytoplasm. Staining for all three proteins was stronger in the cultured cell bodies but was also seen in processes. 


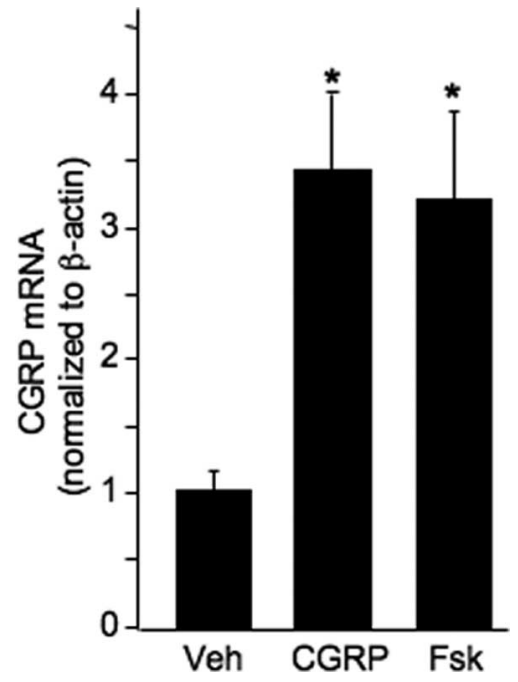

Figure 2. CGRP induction of endogenous (GRP levels. Trigeminal ganglion cultures were treated with vehicle (Veh), $100 \mathrm{~nm} \mathrm{CGRP,} \mathrm{or} 10 \mu \mathrm{m}$ forskolin (Fsk) for $4 \mathrm{~h}$. RNA was isolated, and endogenous CGRP and $\beta$-actin mRNA levels were measured by quantitative RT-PCR. Each primer set spanned an intron to eliminate the risk of a signal from any contaminating genomic DNA. The CGRP levels in each well were normalized to $\beta$-actin levels. There was not any apparent CGRP-dependent change in $\beta$-actin levels. For example, the $\beta$-actin $C t$ values were as follows: vehicle, $15.6 \pm 0.1$; CGRP, $15.8 \pm 0.1$; forskolin, $16.0 \pm 0.1$ (mean and range of duplicate culture wells from one experiment). The means and SEM from three independent experiments (in duplicate except one experiment with single wells) are shown ( ${ }^{*} p<0.05$ ).

\section{CGRP induction of CGRP gene expression}

Given the predicted signaling activity of the CGRP receptor, we reasoned that activation of the trigeminal CGRP receptors would increase CGRP synthesis. RNA was prepared from cultures that had been treated with vehicle or CGRP. Endogenous CGRP mRNA levels were measured by quantitative real-time PCR. CGRP mRNA was increased 3-4-fold after a $4 \mathrm{~h}$ CGRP treatment (Fig. 2). As a positive control, treatment with forskolin yielded a comparable increase in the steady-state levels of CGRP mRNA.

We then asked whether CGRP receptor activation increased CGRP promoter activity. To measure promoter activity in the cultured ganglia, we used a viral vector containing a luciferase reporter gene under control of the $1.25 \mathrm{~kb}$ rat CGRP promoter (Fig. 3A). A sensitive CCD camera imaging system allowed us to measure promoter activity from the same cultures before and after treatments (Fig. $3 B, C$ ). There was a 2.2 -fold increase in CGRP promoter activity after CGRP treatment. As seen with the endogenous mRNA, forskolin treatment caused an increase similar to CGRP treatment, whereas treatment with the vehicle did not affect promoter activity. As a validation of the imaging system assay, similar results were observed using the more traditional luminometer assay to measure the dose-response of promoter activation (Fig. 3D). CGRP promoter activation was observed at CGRP concentrations of $10 \mathrm{~nm}$ and higher with a half-maximal effective concentration $\left(\mathrm{EC}_{50}\right)$ of $2.3 \times 10^{-8} \mathrm{M}$. As a control, receptor antagonists blocked CGRP induction of the promoter (Fig. $3 E$ ). Both CGRP $_{8-37}$, an established antagonist of the CGRP receptor (Poyner et al., 2002), and the nonpeptide CGRP receptor antagonist BIBN4096BS (Olesen et al., 2004) significantly decreased CGRP activation of the promoter. Addition of antagonists alone did not affect promoter activity. This would be consistent with the dose-response curve because the basal amount of endogenous CGRP in the medium is estimated to be in the 10-50 pM range (Durham and Russo, 1999).

We cannot directly test whether CGRP receptor activation leads to increased CGRP secretion because CGRP agonists cannot be distinguished from secreted CGRP. However, increased CGRP secretion from cultured trigeminal ganglia has been reported after forskolin stimulation, which mimics cAMP production by the CGRP receptor (Carruthers et al., 2001). We replicated this finding under our conditions (2.3-fold increase) (data not shown). This supports the prediction that activation of CGRP receptors will increase both synthesis and release of CGRP.

\section{The PKA pathway is required for autoactivation of the CGRP promoter}

To address the mechanism by which CGRP receptors autoactivate the CGRP promoter, we tested two protein kinase A (PKA) inhibitors that act by different mechanisms. H89 is a commonly used inhibitor of PKA, although it can also inhibit other kinases (Davies et al., 2000). 8-Br-RP-cAMPS is a relatively specific cAMP antagonist that prevents activation of PKA (Gjertsen et al., 1995). Both agents prevented CGRP autoactivation of the CGRP promoter (Fig. 4). As a control, H89 did not affect basal promoter activity. For comparison, forskolin induced a comparable activation as seen with CGRP.

Consistent with the functional evidence for CGRP signaling via the PKA pathway, activation of the CGRP receptor increased cAMP levels fourfold to fivefold over control cells (Fig. 5A). The magnitude of the increase is similar to measurements with neonatal rat dorsal root ganglion (DRG) cultures (fourfold to sixfold) (Anderson and Seybold, 2004). The increase was blocked by treatment with the antagonist $\mathrm{CGRP}_{8-37}$. As a positive control, treatment with forskolin caused a robust 40 -fold increase in cAMP levels (Fig. $5 A$ ). The $\mathrm{EC}_{50}$ was $9.0 \pm 5.9 \times 10^{-9}$ M CGRP based on four experiments (Fig. $5 B$ ). This is similar to the $5 \mathrm{nM}$ $\mathrm{EC}_{50}$ of the CGRP receptor in neonatal DRG neurons (Anderson and Seybold, 2004), yet is higher than the $1.4 \mathrm{nM} \mathrm{EC}_{50}$ of recombinant CGRP receptors in HEK293 cells (Aiyar et al., 1999). These data suggested the possibility of limiting levels of a receptor subunit, possibly RAMP1.

\section{CGRP receptor activation is enhanced by Ad CMV-hRAMP1 gene transfer}

To test whether RAMP1 is rate limiting for trigeminal CGRP receptor activation, stimulation of cAMP production was measured after treatment with an adenoviral vector encoding hRAMP1 (Fig. 6A). Cells infected with Ad CMV-hRAMP1 had a decreased $\mathrm{EC}_{50}$ of $2.3 \pm 0.76 \times 10^{-9} \mathrm{M}(n=3)$ and increased maximal response $1.8 \pm 0.19(n=3)$-fold greater than the control cells (Fig. 6B). As a control, cells were infected with a viral vector encoding GFP. Cells infected with the control virus had approximately the same $\mathrm{EC}_{50}, 14.4 \pm 5.24 \times 10^{-9} \mathrm{M}(n=3)$, as noninfected trigeminal cultures, $9.0 \pm 5.9 \times 10^{-9} \mathrm{M} \operatorname{CGRP}(n=$ 4 ), with no significant change in the maximal response. In addition to the changes in the $\mathrm{EC}_{50}$ and maximal response, we observed a consistent increase in the Hill coefficient from $0.91 \pm$ 0.15 to $2.6 \pm 0.8$ (SD; $n=3 ; p<0.05)$. These results demonstrate that hRAMP1 gene transfer increases the sensitivity and activity of the CGRP receptor on trigeminal ganglia neurons.

\section{Generation of transgenic mice expressing hRAMP1 in the nervous system}

To test the role of hRAMP1 in vivo, a double-transgenic mouse expressing hRAMP1 in the nervous system was generated. A GFP-hRAMP1 transgenic line was first generated using a vector containing the ubiquitously active $\mathrm{CX} 1$ promoter upstream of separate GFP and hRAMP1 cDNAs (Fig. 7). The GFP cDNA 
includes a translational stop sequence and a polyadenylation signal, which prevent expression of hRAMP1 in these mice. In this way, hRAMP1 expression is dependent on cre recombinase excision of GFP at flanking loxP sites. For these studies, we used transgenic mice containing the cre gene under control of the nervous systemspecific promoter and enhancer from the rat nestin gene. The nestin-cre transgene is expressed by embryonic day 11, primarily in progenitor cells of the CNS and peripheral nervous system and some isolated cells in the heart and kidney (Tronche et al., 1999; Graus-Porta et al., 2001; Dubois et al., 2006). Thus, hRAMP1 should be expressed primarily in neurons and glia in the double-transgenic progeny containing both the GFP-hRAMP1 and nestin-cre transgenes.

Expression of hRAMP1 RNA in the nervous system of the double-transgenic mice was demonstrated by RT-PCR amplification using primers specific for hRAMP1 that do not detect mouse RAMP1. Expression was detected in the nestin/hRAMP1 brain, trigeminal ganglion, spinal cord, and DRG, but not in the heart, liver, or stomach (Fig. 8 A). Expression was also not detected in the kidney or small intestine (data not shown). As predicted, hRAMP1 RNA was not detected in tissues from the single-transgenic mice containing only GFP-hRAMP1 (Fig. 8A) or nestin-cre (data not shown). The pattern of hRAMP1 expression is consistent with qualitative observations of decreased GFP fluorescence in the nervous tissue, but not in non-nervous tissue, of doubletransgenic mice compared with the singletransgenic control mice (data not shown). As controls, GAPDH control RNA was detected from all samples.

The levels of transgene hRAMP1 RNA were compared with endogenous mouse RAMP1 by Q-PCR (Fig. 8 B). In the nestin/hRAMP1 mice, the hRAMP1 levels were approximately one-half of the mouse RAMP1 levels in the brain. The mouse RAMP1 levels were unchanged between nestin/hRAMP1 and nestin-cre control mice. The total RAMP1 levels in the nestin/hRAMP1 brains were $1.4 \pm 0.3$-fold greater than in the nestin-cre mice. Similar, although more variable, results were seen with the trigeminal ganglia (Fig. $8 B$ ). The total RAMP1 levels were estimated to be $3.3 \pm 1.3$-fold greater in the nestin/ hRAMP1 mice. Thus, there appears to be a relatively modest, approximately twofold increase in total RAMP1 RNA levels in the brain and trigeminal ganglia of the nestin/hRAMP1 transgenic mice.

Unfortunately, we cannot confidently quantify RAMP1 pro-

\section{A Ad rCGRP-Luc}
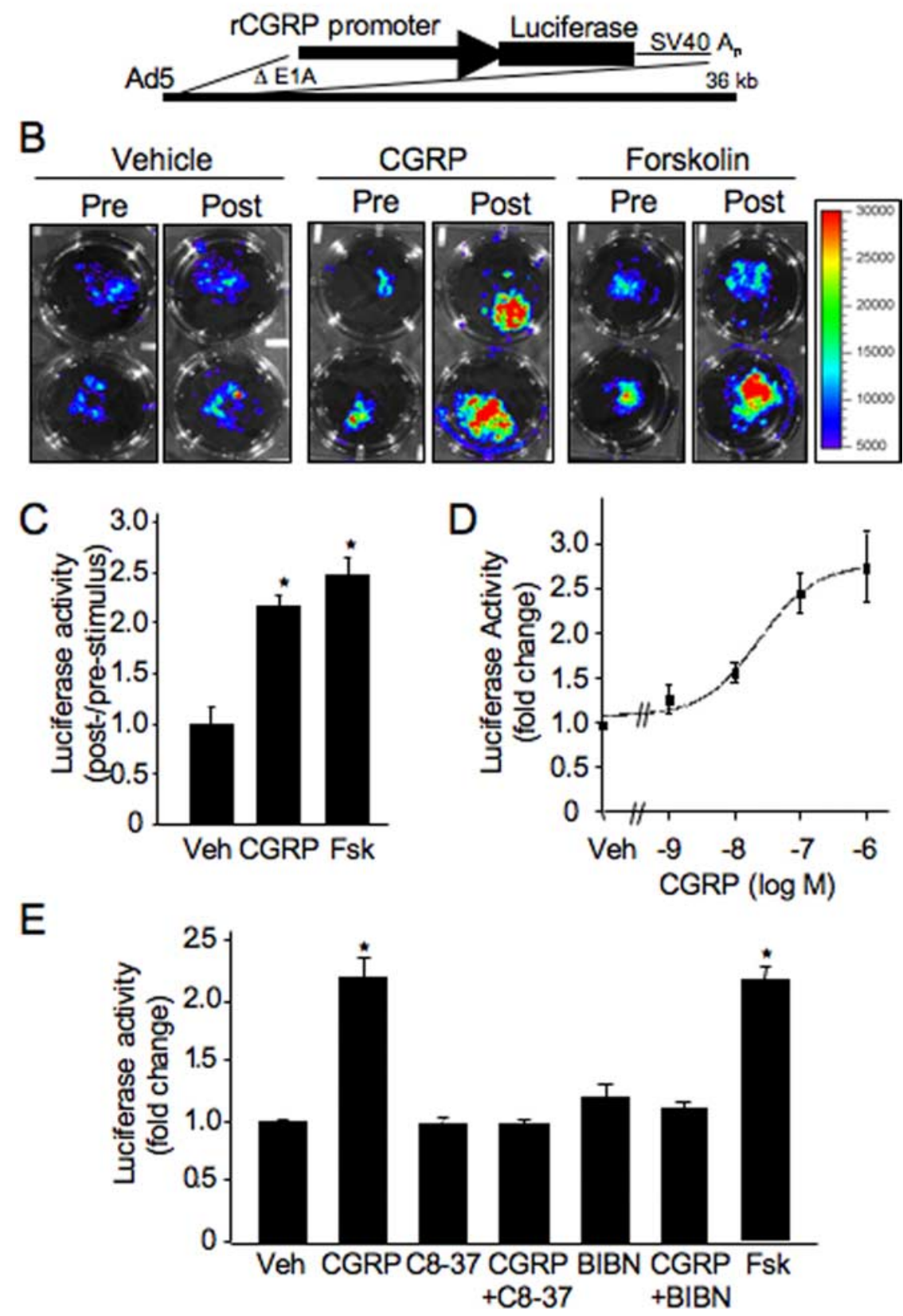

Figure 3. CGRP induction of CGRP promoter activity. $\boldsymbol{A}$, Schematic of the rat CGRP promoter reporter viral vector (Ad rCGRPLuc). $\boldsymbol{B}$, Bioluminescence images of cultures infected with Ad rCGRP-Luc. Prestimulus images (Pre) were taken immediately before treatment with vehicle, $100 \mathrm{~nm}$ CGRP, or $10 \mu \mathrm{m}$ forskolin. Poststimulus images (Post) were taken after $4 \mathrm{~h}$. Coverslips are not in identical positions within the wells in the Pre and Post images. The calibration scale is in photons per second per steradian per centimeter squared. $\boldsymbol{C}$, The prestimulus and poststimulus light levels were measured and reported as the ratio of poststimulus to prestimulus light after treatment with vehicle (Veh), $100 \mathrm{~nm}$ CGRP, or $10 \mu \mathrm{m}$ forskolin (Fsk) for $4 \mathrm{~h}$. The means \pm SEM from three independent experiments, each in duplicate or triplicate, are shown $\left({ }^{*} p<0.05\right)$. D , Dose-response of CGRP activation of CGRP promoter activity. Cultures were treated for $4 \mathrm{~h}$ with vehicle or the indicated concentrations of CGRP. Luciferase activities measured by a luminometer were normalized to vehicle-treated wells and reported as the mean \pm SEM from three independent experiments in duplicate. $\boldsymbol{E}$, CGRP receptor antagonist controls. Cultures were treated for $4 \mathrm{~h}$ with vehicle, $100 \mathrm{~nm}$ (GRP, $500 \mathrm{~nm}$ antagonist CGRP $_{8-37}$ (C8-37), $100 \mathrm{~nm}$ CGRP plus $500 \mathrm{~nm} \mathrm{CGRP}_{8-37}$ (added 30 min before CGRP), $10 \mathrm{~nm}$ BIBN4096BS (BIBN), or 100 nм CGRP plus 10 nм BIBN4096BS (added 30 min before (GRP), or $10 \mu \mathrm{m}$ forskolin. The values were normalized to vehicle-treated wells and reported as the mean \pm SEM from three independent experiments in duplicate $\left(^{*} p<0.05\right)$.

tein levels. Our existing RAMP1 antibody often yields an unexplainably high background and has a likely species bias because the epitope was designed against a mouse, not human, RAMP1 peptide. Within this caveat, Western blots of lysates prepared 


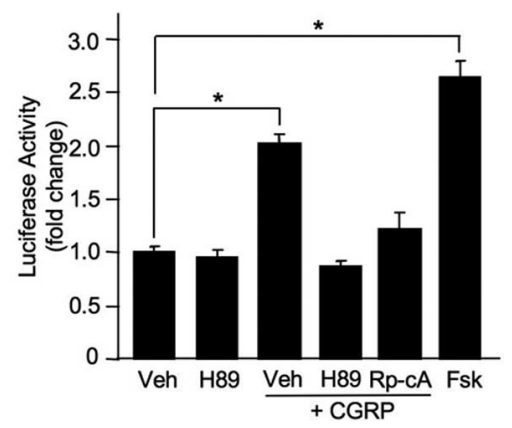

Figure 4. CGRP induction of CGRP promoter activity requires the PKA pathway. Cultures were infected with Ad rCGRP-Luc, then treated for $4 \mathrm{~h}$ with vehicle (Veh), $10 \mu \mathrm{m}$ H89 (PKA inhibitor), $10 \mu \mathrm{m}$ forskolin (Fsk), or $100 \mathrm{~nm}$ CGRP after a 20 -30 min pretreatment with vehicle, $10 \mu \mathrm{m} \mathrm{H89}$, or $25 \mu \mathrm{m}$ 8-Br-Rp-cAMPS (Rp-cA) (inactive cAMP analog). There was no difference between the DMSO and ethanol vehicles; thus, the pooled vehicle data are shown. Luciferase activity was measured by a luminometer and normalized to the vehicle control. The mean \pm SEM from three to four independent experiments in duplicate is shown $\left({ }^{*} p<0.05\right.$ compared with vehicle).
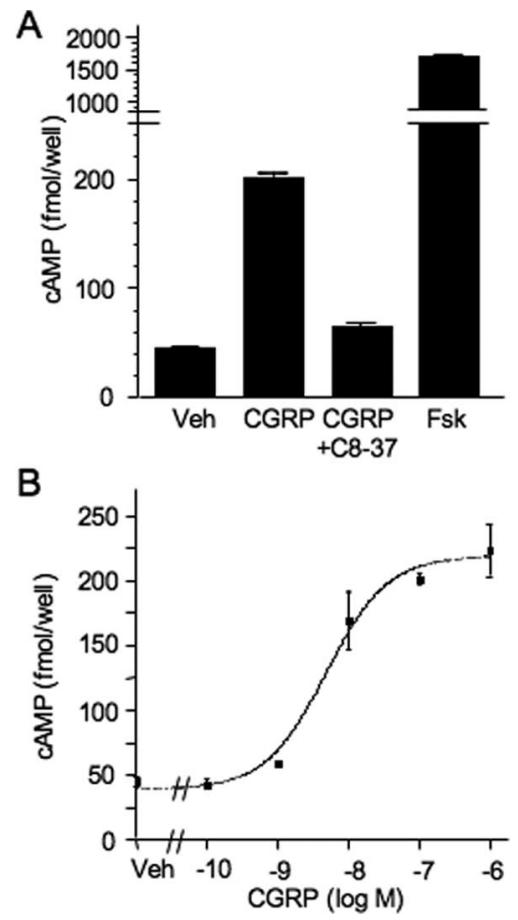

Figure 5. CGRP induction of CAMP in trigeminal ganglion cultures. $\boldsymbol{A}$, Intracellular cAMP levels were measured from cultures treated with vehicle (Veh) or $100 \mathrm{~nm}$ (GRP for $10 \mathrm{~min}$. As controls, cultures were treated with $100 \mathrm{~nm}$ CGRP plus $500 \mathrm{~nm}$ antagonist CGRP $_{8-37}$ (C8-37) or $10 \mu \mathrm{m}$ forskolin (Fsk). A representative of four independent experiments is shown. Each experiment was performed in duplicate, and the error bars indicate the range. $\boldsymbol{B}$, Cultures were treated with the indicated concentrations of GRP or vehicle for $10 \mathrm{~min}$. CAMP levels were measured and reported as the mean \pm range from a representative experiment performed in duplicate.

from the nestin/hRAMP1 mice had a $1.9 \pm 0.1$-fold greater RAMP1 signal than control littermates (Fig. $8 C$ ). We then measured CLR and RCP levels (Fig. 8C). There were comparable levels of CLR and RCP $(1.1 \pm 0.1-$ and $1.0 \pm 0.1$-fold, respectively). These observations are consistent with the expected ability of hRAMP1 to increase CLR activity without increasing total CLR levels and the ability of RCP to couple to CLR independent of the type of RAMP (Evans et al., 2000; Hay et al., 2006b).

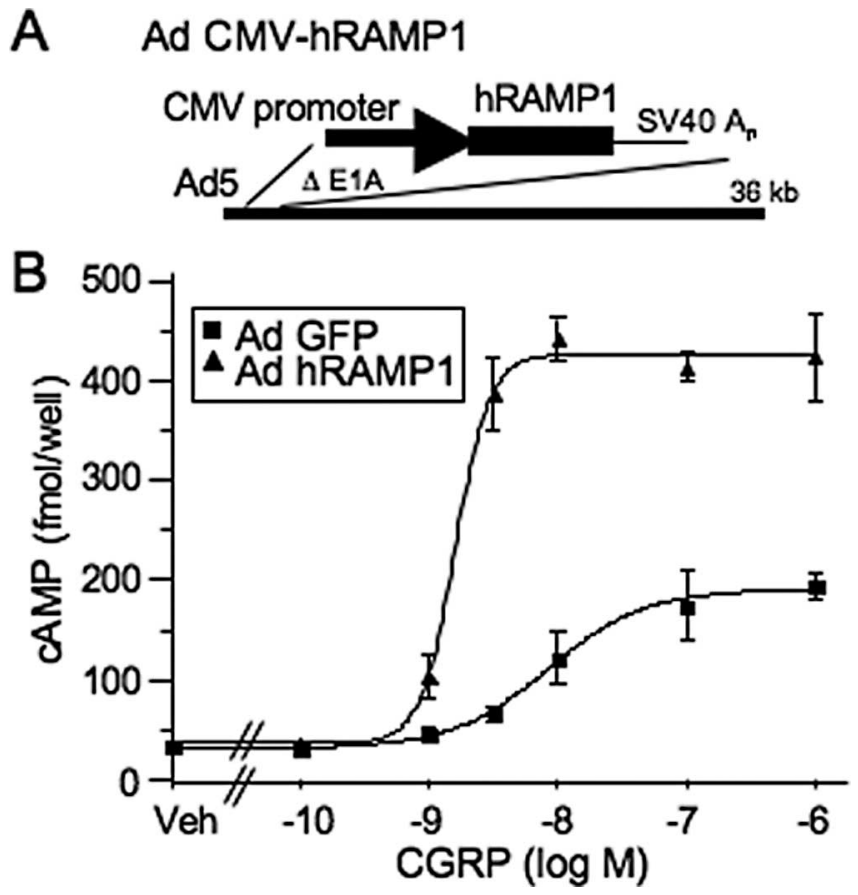

Figure 6. Ad CMV-hRAMP1 gene transfer increases CGRP induction of CAMP. A, Schematic of the Ad CMV-hRAMP1 vector. B, Cultured rat trigeminal ganglia cells were infected with either the control virus Ad CMV-GFP or Ad CMV-hRAMP1. After $24 \mathrm{~h}$, the cultures were treated for 10 min with vehicle (Veh) or the indicated concentrations of CGRP. A representative figure of three experiments shows a decreased $\mathrm{EC}_{50}$ and increased maximal response in cultures containing recombinant hRAMP1. The mean and range of duplicate samples are shown.
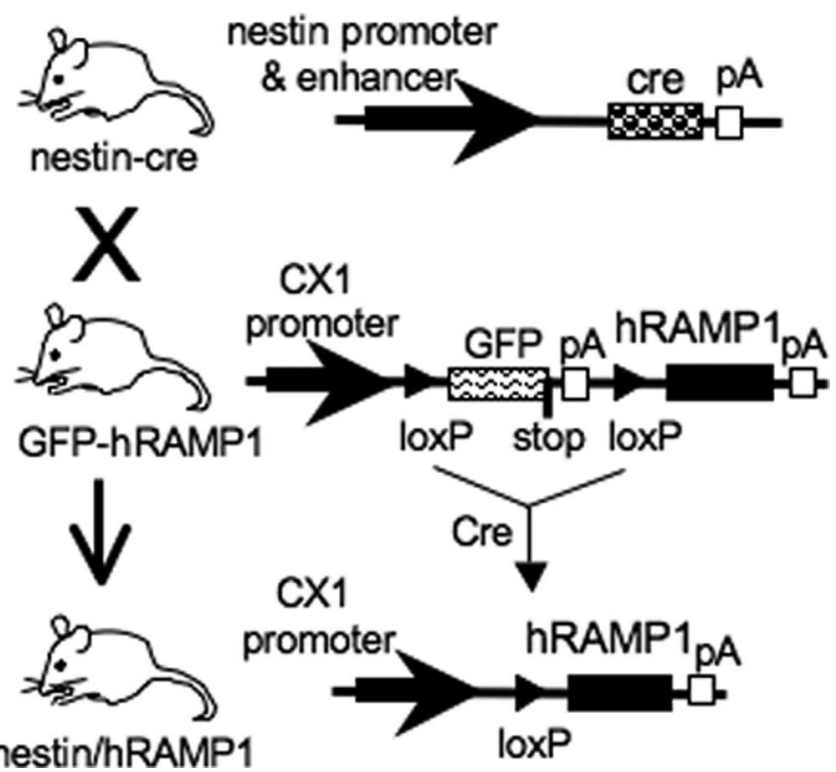

Figure 7. Strategy for generating hRAMP1 transgenic mice. Male transgenic mice with the rat nestin promoter and enhancer driving cre recombinase (nestin-cre) were mated with female transgenic mice with the $\mathrm{CX} 1$ promoter and GFP-stop- hRAMP1 cassette that is flanked by loxP sites (GFP- hRAMP1). CX1 drives ubiquitous expression of GFP, but not hRAMP1, because the GFP cDNA has a translation stop codon (stop) and a polyadenylation signal (pA). Double transgenic offspring that have both the nestin-cre and GFP- hRAMP1 transgenes (nestin/hRAMP1) are predicted to have cre-mediated excision of the GFP-stop sequence at the flanking loxP sites. The resultant $h$ RAMP1 transgene is then expressed from the $C X 1$ promoter in the nervous system. 


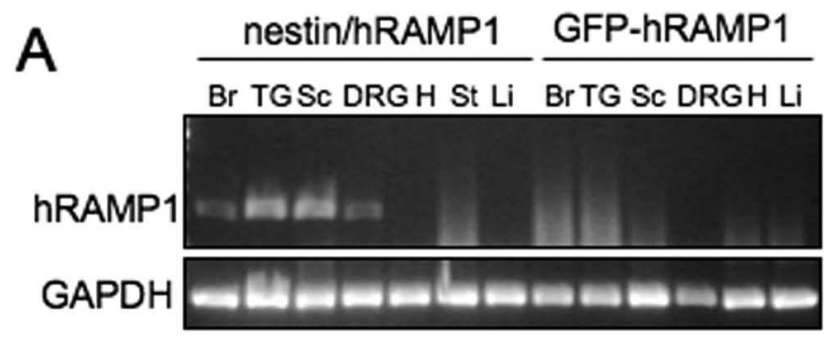

B

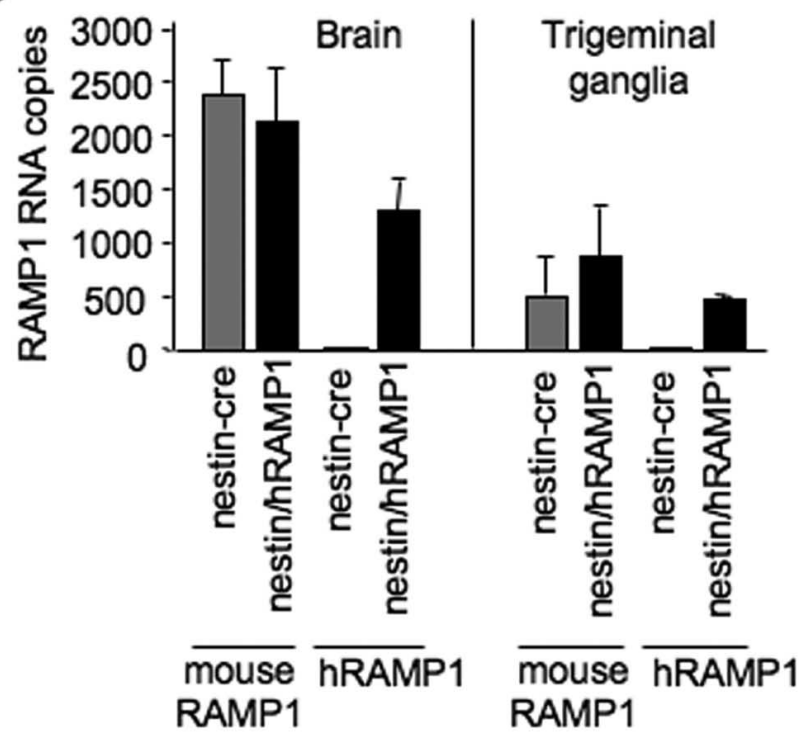

C

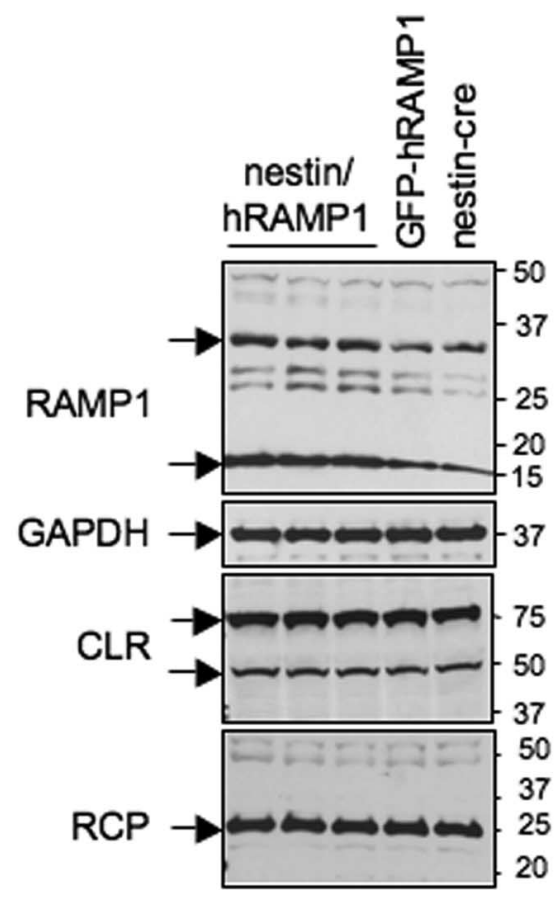

Figure 8. Expression of hRAMP1 in the mouse nervous system. $A$, RT-PCR detection of hRAMP1 RNA expression. hRAMP1 expression was detected in the brain (Br), spinal cord ( $\mathrm{Sc}$ ), and peripheral ganglia of the double-transgenic nestin/hRAMP1 mice, but not in singletransgenic GFP-hRAMP1 or nestin-cre mice (data not shown). The RT-PCR product for hRAMP1 is $228 \mathrm{bp}$, and the GAPDH control product is $452 \mathrm{bp}$. TG, Trigeminal ganglia; DRG, dorsal root ganglia; $H$, heart; St, stomach; Li, liver. $\boldsymbol{B}$, Measurement of mouse and human RAMP1 RNA levels by Q-PCR. Brain RNA was independently isolated and amplified from three nestin/ hRAMP1 mice and three nestin-cre control littermates (each in duplicate; left panel) and from two of each mice for trigeminal ganglia (each in duplicate; right panel). The mean \pm SEM copies
hRAMP1 enhancement of CGRP-induced

subcutaneous inflammation

To test whether trigeminal RAMP1 was functionally rate limiting in vivo, we used plasma extravasation as a measure of CGRPinduced subcutaneous inflammation. The rationale is that increased trigeminal hRAMP1 should increase CGRP-triggered release of substance $\mathrm{P}$ from trigeminal afferent processes, which causes the extravasation component of neurogenic inflammation. Both substance $P$ and CGRP cause redness and swelling near the injection site in the skin (Brain and Grant, 2004). To visualize and measure extravasation, Evans blue dye was intravenously injected into the mice. Leakage of the dye into subcutaneous tissues after local injection of vehicle or CGRP was visually monitored and quantitated by extraction of the dye from facial tissue. The facial skin receives sensory innervation from the trigeminal ganglion. After subcutaneous injection of CGRP, a blue region was apparent on the facial skin of the double-transgenic mice that was much greater than that seen on the control single-transgenic mice (Fig. 9A). There was $2.2 \pm 0.2$-fold greater dye leakage in the whiskerpads of double-transgenic mice than in the singletransgenic control mice (Fig. 9B). Coinjection with the CGRP ${ }_{8-37}$ antagonist blocked the extravasation. Similar results were also observed when the paws were injected with CGRP and CGRP with CGRP $_{8-37}$ (data not shown), which is consistent with DRG expression of the hRAMP1 transgene.

We did two experiments to support the conclusion that hRAMP1 in trigeminal ganglia neurons was responsible for the enhanced CGRP-induced inflammation. First, we confirmed that there was not any hRAMP1 expression in cell bodies within the subcutaneous tissue. hRAMP1 RNA was not detectable in the whiskerpad or paw tissues (Fig. 9C). As controls, hRAMP1 RNA was detected from the brain and trigeminal ganglia of the same mice, and GAPDH RNA was detected from all samples.

Second, we established that increased neuronal hRAMP1 also increased CGRP-evoked release of substance P. The approach was to measure substance $P$ release from cultured trigeminal ganglia neurons. After Ad CMV-hRAMP1 gene transfer, there was enhanced CGRP-induced release of substance P (Fig. 10). This was most striking at a low concentration of CGRP ( $5 \mathrm{nM})$. At this concentration, CGRP did not increase substance P release from control cultures but did cause a significant increase from Ad CMV-hRAMP1-infected cultures. As a control, forskolin treatment of both the control and Ad CMV-hRAMP1 cultures caused an $\sim 2.5$-fold increase in substance $P$ release. The amount of substance P release evoked by $100 \mathrm{~nm}$ CGRP treatment of Ad CMVhRAMP1 cultures was similar to the level induced by forskolin.

\section{Discussion}

We have provided evidence for functional CGRP receptors on trigeminal ganglion neurons. After stimulation, the receptors activated cAMP-dependent pathways that increased CGRP gene expression. We also observed promoter activation by cAMP-

of mouse and human RAMP1 per sample is shown. A small signal forhRAMP1 was detected from some nestin-cre mice. However, the melt curves were heterogeneous, and only a smear was detected on gels; thus, those samples were excluded. C, RAMP1, CLR, and RCP Western blots of trigeminal ganglia lysates from three nestin/hRAMP1 mice and control GFP-RAMP1 and nestin-cre mice. The same filter was sequentially incubated with antisera against RAMP1, CLR, $\mathrm{RCP}$, and GAPDH (loading control). The proteins are indicated by arrows. Mature CLR is $\sim 70$ $\mathrm{kDa}$; the $\sim 50 \mathrm{kDa}$ species is most likely core-glycosylated CLR (McLatchie et al., 1998). RAMP1 is known to exist as monomer $(\sim 15 \mathrm{kDa})$ and dimer $(\sim 30 \mathrm{kDa})$, even under denaturing conditions (McLatchie et al., 1998). 

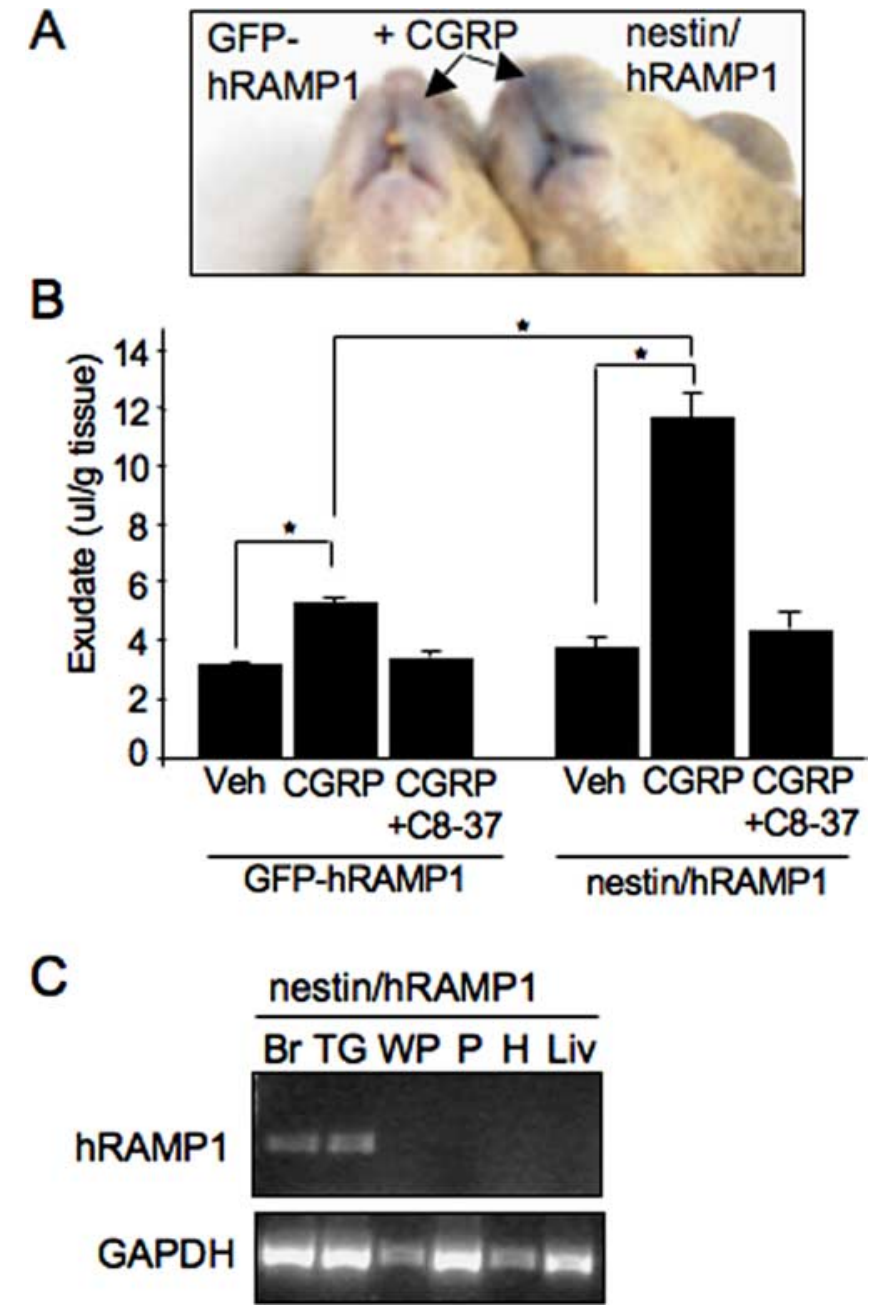

Figure 9. Enhanced subcutaneous facial plasma extravasation by neuronal hRAMP1 expression. $A$, Evans blue dye was injected into the blood to measure plasma extravasation. A representative image of greater dye extravasation after (GRP injection ( 5 pmol) into the left lip region of a nestin/hRAMP1 double-transgenic mouse than a GFP-hRAMP1 single-transgenic littermate is shown. $\boldsymbol{B}$, The amount of Evans blue dye in the subcutaneous tissue of the whiskerpad was measured $5-10$ min after injection of 5 pmol of CGRP ( $n=7$ single transgenic; $n=$ 7 double transgenic), PBS vehicle (Veh) ( $n=3$ single transgenic; $n=3$ double transgenic) or 5 pmol of (GRP plus 25 pmol of GRP $_{8-37}(n=4$ double transgenic; $n=3$ single transgenic). The mean \pm SEM of dye in the exudate from the double-transgenic mice and control singletransgenic mice are given $\left({ }^{*} p<0.01\right)$. C, hRAMP1 RNA detected by RT-PCR from nervous tissue, but not whiskerpad or paw tissues, isolated from the double-transgenic nestin/hRAMP1 mice. The hRAMP1 RT-PCR product is $228 \mathrm{bp}$, and the GAPDH control is $452 \mathrm{bp}$. Br, Brain; TG, trigeminal ganglia; WP, whiskerpad; P, paw; H, heart; Liv, liver.

dependent activation of mitogen-activated protein (MAP) kinases (C. S. Winborn, unpublished data). These observations are in agreement with the established coupling of the CGRP receptor to G $\alpha$ s (Poyner et al., 2002; Brain and Grant, 2004) and activation of MAP kinases seen in other systems, including DRG (Anderson and Seybold, 2004). Autoactivation of CGRP synthesis indicates that elevated release of trigeminal CGRP could generate a selfsustaining feedback loop similar to those reported for other neuroendocrine peptides (Hahm and Eiden, 1998). The presence of CGRP receptors on DRG neurons (Segond von Banchet et al., 2002; Anderson and Seybold, 2004; Cottrell et al., 2005; Natura et al., 2005) suggests that this feedback may be a shared feature of sensory ganglia.

The relatively high $\mathrm{EC}_{50}$ values from both the cAMP and promoter studies suggested the possibility that a receptor subunit

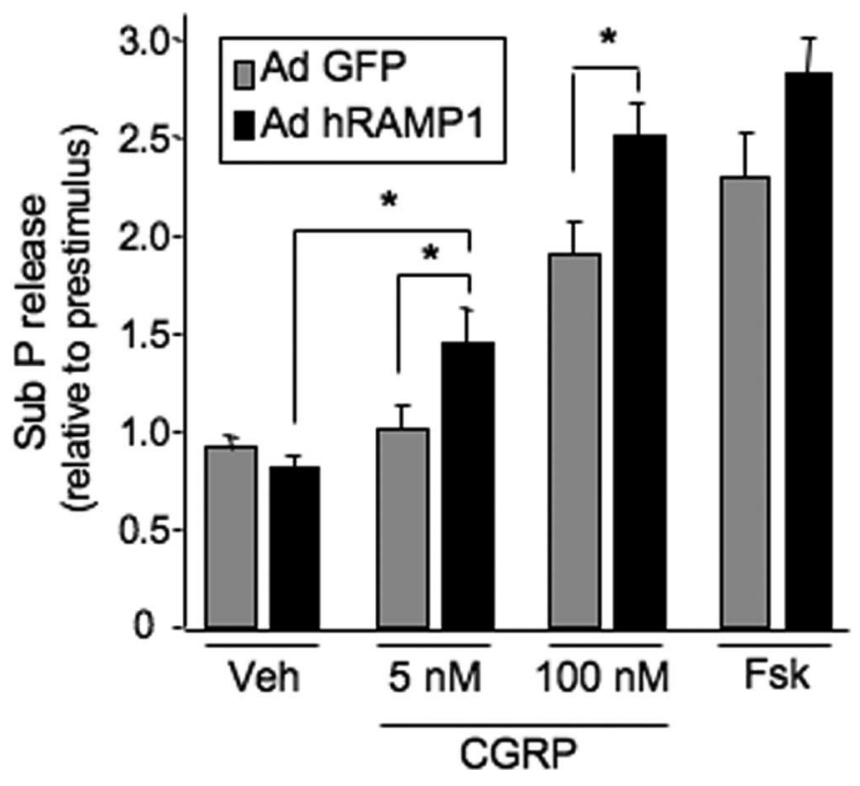

Figure 10. Ad CMV-hRAMP1 enhancement of CGRP-induced release of substance P (Sub P). Primary cultures of rat trigeminal ganglia were infected with either Ad CMV-hRAMP1 or the control Ad CMV-GFP virus. The amount of substance $P$ in the medium was measured from the same cultures before and after stimulation with vehicle (Veh), 5 or $100 \mathrm{~nm}$ (GRP, or $10 \mu \mathrm{m}$ forskolin (Fsk). Samples were taken after a $1 \mathrm{~h}$ prestimulus period followed by a $1 \mathrm{~h}$ stimulus period. The ratios of stimulus-evoked to prestimulus substance $P$ are reported as the mean \pm SEM from three independent experiments in duplicate $\left({ }^{*} p<0.05\right)$.

might be limiting. Because the CLR protein is activated by three different RAMP subunits, yet only RAMP1 constitutes a highaffinity CGRP receptor, we reasoned that RAMP1 might be limiting for CGRP action. Our findings demonstrate that RAMP1 levels are functionally rate limiting in trigeminal ganglia in culture and in vivo. At a cellular level, hRAMP1 increased CGRPinduced production of cAMP and release of substance P. In the transgenic mice, the overexpression of hRAMP1 increased CGRP induction of subcutaneous inflammation. By using targeted expression of hRAMP1 in the nervous system, these data demonstrate that the neuronal CGRP receptor is an important modulator of neurogenic inflammation.

To our knowledge, this is the first study demonstrating an effect of RAMP1 overexpression in neurons or any tissue in vivo. The increased receptor sensitivity to CGRP after RAMP1 gene transfer is in agreement with the established role of RAMP1 in specifying ligand binding to CLR (Hay et al., 2006b). In addition to ligand specificity, RAMP1 also influences CLR glycosylation and cell-surface trafficking (Hay et al., 2006b). The increased maximal response with the cultured neurons and increased sensitivity in vivo without an apparent increase in total CLR or RCP are consistent with an increased number of receptors at the cell surface. An unexpected finding was that the Hill coefficient was increased by overexpression of hRAMP1. As reported previously, the CGRP receptor in control cells had a Hill coefficient near one (Fernandez et al., 2003). The increased Hill coefficient after hRAMP1 overexpression is suggestive that there may be cooperativity among receptor subunits and/or a change in stimulus response coupling. In this regard, it is possible that RCP or another factor may be influenced by hRAMP1.

Although we have focused on RAMP1 activation of CLR, RAMP1 and other RAMPs can also interact with additional members of the G-protein-coupled receptor family (Christopoulos et al., 2003; Bouschet et al., 2005). In particular, RAMP1 can 
interact with the calcitonin receptor to generate an amylin receptor that can also bind CGRP (Christopoulos et al., 1999; Muff et al., 1999). However, there are not any reports of calcitonin or amylin receptors in trigeminal ganglia, and the ability of BIBN4096BS to completely block receptor activity is suggestive of a CLR/RAMP1 complex (Hay et al., 2006a).

In addition to direct effects on CLR, it is possible that the overexpressed RAMP1 may also compete with other RAMPs for CLR. RAMP2 and RAMP3 RNAs are present in the mouse trigeminal ganglia (data not shown). Overexpression of RAMP1 has been reported to shift a CLR/RAMP2 adrenomedullin receptor to become a CGRP receptor in an osteoblast-like cell line (Buhlmann et al., 1999). Adrenomedullin and CGRP have overlapping activities, including blood vessel dilation (Brain and Grant, 2004). Recently, Brain and colleagues described the vascular properties of transgenic mice with overexpressed RAMP2 in smooth muscle (Tam et al., 2006). In these mice, there was increased adrenomedullin-induced vasodilation, whereas CGRPinduced dilation remained the same. However, there was decreased potentiation of substance $\mathrm{P}$-induced edema in response to low concentrations of CGRP, suggesting some competition between RAMP1 and RAMP2 in the cutaneous microvasculature. Whether there is competition between RAMPs in our hRAMP1 transgenic mice remains to be determined. Future characterization of the transgenic hRAMP1 mouse phenotype will address these and other activities that may be influenced by RAMP1.

Identification of trigeminal ganglion CGRP receptors that are inhibited by the antimigraine drug BIBN4096BS adds a fourth potential site of CGRP action in migraine. Indeed, the pertinent sites of CGRP and BIBN4096BS actions during migraine remain to be established (Durham, 2004; Strassman and Levy, 2006). Based on recent evidence, peripheral CGRP receptors at the dura alone are not sufficient to activate trigeminal ganglion nociceptors (Fischer et al., 2005; Levy et al., 2005). Although this does not preclude a peripheral autoreceptor role, it does emphasize the potential importance of autoreceptors on ganglion cell bodies and/or central projections in the trigeminocervical complex of the brainstem. In particular, the precedence for regulated neuropeptide release within the trigeminal ganglia (Matsuka et al., 2001; Ulrich-Lai et al., 2001) supports the possibility of autocrine gene regulation at the cell body.

The discovery that RAMP1 is functionally rate limiting in the trigeminal ganglion provides a new perspective on the regulation of CGRP receptor activity in trigeminal pathologies such as migraine. Relatively little is currently known about the regulation of RAMP1 levels, but observations that RAMP1 can be induced by dexamethasone (Frayon et al., 2000) and during hypoxia (Cueille et al., 2005) suggest that dynamic changes in RAMP1 levels may underlie certain pathologies. We propose that elevated neuronal RAMP1 could potentially sensitize the trigeminal ganglia of individuals to CGRP actions. These actions would include increased CGRP synthesis and increased neurogenic inflammation, which could potentially help sustain and intensify the nociceptive actions of CGRP in migraine.

\section{References}

Aiyar N, Disa J, Stadel JM, Lysko PG (1999) Calcitonin gene-related peptide receptor independently stimulates $3^{\prime}, 5^{\prime}$-cyclic adenosine monophosphate and $\mathrm{Ca}^{2+}$ signaling pathways. Mol Cell Biochem 197:179-185.

Anderson LE, Seybold VS (2004) Calcitonin gene-related peptide regulates gene transcription in primary afferent neurons. J Neurochem 91:1417-1429.

Bouschet T, Martin S, Henley JM (2005) Receptor-activity-modifying pro- teins are required for forward trafficking of the calcium-sensing receptor to the plasma membrane. J Cell Sci 118:4709-4720.

Brain SD, Grant AD (2004) Vascular actions of calcitonin gene-related peptide and adrenomedullin. Physiol Rev 84:903-934.

Buhlmann N, Leuthauser K, Muff R, Fischer JA, Born W (1999) A receptor activity modifying protein (RAMP)2-dependent adrenomedullin receptor is a calcitonin gene-related peptide receptor when coexpressed with human RAMP1. Endocrinology 140:2883-2890.

Carruthers AM, Sellers LA, Jenkins DW, Jarvie EM, Feniuk W, Humphrey PP (2001) Adenosine A(1) receptor-mediated inhibition of protein kinase A-induced calcitonin gene-related peptide release from rat trigeminal neurons. Mol Pharmacol 59:1533-1541.

Christopoulos A, Christopoulos G, Morfis M, Udawela M, Laburthe M, Couvineau A, Kuwasako K, Tilakaratne N, Sexton PM (2003) Novel receptor partners and function of receptor activity-modifying proteins. J Biol Chem 278:3293-3297.

Christopoulos G, Perry KJ, Morfis M, Tilakaratne N, Gao Y, Fraser NJ, Main MJ, Foord SM, Sexton PM (1999) Multiple amylin receptors arise from receptor activity-modifying protein interaction with the calcitonin receptor gene product. Mol Pharmacol 56:235-242.

Cottrell GS, Roosterman D, Marvizon JC, Song B, Wick E, Pikios S, Wong H, Berthelier C, Tang Y, Sternini C, Bunnett NW, Grady EF (2005) Localization of calcitonin receptor-like receptor and receptor activity modifying protein 1 in enteric neurons, dorsal root ganglia, and the spinal cord of the rat. J Comp Neurol 490:239-255.

Cueille C, Birot O, Bigard X, Hagner S, Garel JM (2005) Posttranscriptional regulation of CRLR expression during hypoxia. Biochem Biophys Res Commun 326:23-29.

Davies SP, Reddy H, Caivano M, Cohen P (2000) Specificity and mechanism of action of some commonly used protein kinase inhibitors. Biochem J 351:95-105.

Dikalova A, Clempus R, Lassegue B, Cheng G, McCoy J, Dikalov S, San Martin A, Lyle A, Weber DS, Weiss D, Taylor WR, Schmidt HH, Owens GK, Lambeth JD, Griendling KK (2005) Nox1 overexpression potentiates angiotensin II-induced hypertension and vascular smooth muscle hypertrophy in transgenic mice. Circulation 112:2668-2676.

Dubois NC, Hofmann D, Kaloulis K, Bishop JM, Trumpp A (2006) NestinCre transgenic mouse line Nes-Crel mediates highly efficient Cre/loxP mediated recombination in the nervous system, kidney, and somitederived tissues. Genesis 44:355-360.

Durham PL (2004) CGRP-receptor antagonists-a fresh approach to migraine therapy? N Engl J Med 350:1073-1075.

Durham PL, Russo AF (1999) Regulation of calcitonin gene-related peptide secretion by a serotonergic antimigraine drug. J Neurosci 19:3423-3429.

Durham PL, Russo AF (2003) Stimulation of the calcitonin gene-related peptide enhancer by mitogen-activated protein kinases and repression by an antimigraine drug in trigeminal ganglia neurons. J Neurosci 23:807-815.

Durham PL, Dong PX, Belasco KT, Kasperski J, Gierasch WW, Edvinsson L, Heistad DD, Faraci FM, Russo AF (2004) Neuronal expression and regulation of CGRP promoter activity following viral gene transfer into cultured trigeminal ganglia neurons. Brain Res 997:103-110.

Edvinsson L, Cantera L, Jansen-Olesen I, Uddman R (1997) Expression of calcitonin gene-related peptidel receptor mRNA in human trigeminal ganglia and cerebral arteries. Neurosci Lett 229:209-211.

Edvinsson L, Alm R, Shaw D, Rutledge RZ, Koblan KS, Longmore J, Kane SA (2002) Effect of the CGRP receptor antagonist BIBN4096BS in human cerebral, coronary and omental arteries and in SK-N-MC cells. Eur J Pharmacol 434:49-53.

Evans BN, Rosenblatt MI, Mnayer LO, Oliver KR, Dickerson IM (2000) CGRP-RCP, a novel protein required for signal transduction at calcitonin gene-related peptide and adrenomedullin receptors. J Biol Chem 275:31438-31443.

Fabbretti E, D'Arco M, Fabbro A, Simonetti M, Nistri A, Giniatullin R (2006) Delayed upregulation of ATP P2X3 receptors of trigeminal sensory neurons by calcitonin gene-related peptide. J Neurosci 26:6163-6171.

Fernandez HL, Chen M, Nadelhaft I, Durr JA (2003) Calcitonin generelated peptides: their binding sites and receptor accessory proteins in adult mammalian skeletal muscles. Neuroscience 119:335-345.

Fischer MJ, Koulchitsky S, Messlinger K (2005) The nonpeptide calcitonin gene-related peptide receptor antagonist BIBN4096BS lowers the activity 
of neurons with meningeal input in the rat spinal trigeminal nucleus. J Neurosci 25:5877-5883.

Frayon S, Cueille C, Gnidehou S, de Vernejoul MC, Garel JM (2000) Dexamethasone increases RAMP1 and CRLR mRNA expressions in human vascular smooth muscle cells. Biochem Biophys Res Commun 270:1063-1067.

Gallai V, Sarchielli P, Floridi A, Franceschini M, Codini M, Glioti G, Trequattrini A, Palumbo R (1995) Vasoactive peptide levels in the plasma of young migraine patients with and without aura assessed both interictally and ictally. Cephalalgia 15:384-390.

Gjertsen BT, Mellgren G, Otten A, Maronde E, Genieser HG, Jastorff B, Vintermyr OK, McKnight GS, Doskeland SO (1995) Novel (Rp)cAMPS analogs as tools for inhibition of cAMP-kinase in cell culture. Basal cAMP-kinase activity modulates interleukin-1 beta action. J Biol Chem 270:20599-20607.

Goadsby PJ (2005) Can we develop neurally acting drugs for the treatment of migraine? Nat Rev Drug Discov 4:741-750.

Goadsby PJ (2006) Migraine: emerging treatment options for preventive and acute attack therapy. Expert Opin Emerg Drugs 11:419-427.

Goadsby PJ, Edvinsson L, Ekman R (1990) Vasoactive peptide release in the extracerebral circulation of humans during migraine headache. Ann Neurol 28:183-187.

Goadsby PJ, Lipton RB, Ferrari MD (2002) Migraine-current understanding and treatment. N Engl J Med 346:257-270.

Graus-Porta D, Blaess S, Senften M, Littlewood-Evans A, Damsky C, Huang Z, Orban P, Klein R, Schittny JC, Muller U (2001) Beta1-class integrins regulate the development of laminae and folia in the cerebral and cerebellar cortex. Neuron 31:367-379.

Hahm SH, Eiden LE (1998) Cis-regulatory elements controlling basal and inducible VIP gene transcription. Ann NY Acad Sci 865:10-26.

Hay DL, Christopoulos G, Christopoulos A, Sexton PM (2006a) Determinants of 1-piperidinecarboxamide, N-[2-[[5-amino-1-[[4-(4-pyridinyl)1-piperazinyl $]$ carbonyl $]$ pentyl $]$ amino $]-1-[(3,5$-dibromo-4-

hydroxyphenyl)methyl]-2-oxoethyl]-4-(1,4-dihydro-2-oxo-3(2H)quinazolinyl) (BIBN4096BS) affinity for calcitonin gene-related peptide and amylin receptors-the role of receptor activity modifying protein 1. Mol Pharmacol 70:1984-1991.

Hay DL, Poyner DR, Sexton PM (2006b) GPCR modulation by RAMPs. Pharmacol Ther 109:173-197.

John JM, Kaneko M, Hammond DL (1998) Intrathecal bicuculline does not increase formalin-induced inflammation. Brain Res 794:320-324.

Juhasz G, Zsombok T, Modos EA, Olajos S, Jakab B, Nemeth J, Szolcsanyi J, Vitrai J, Bagdy G (2003) NO-induced migraine attack: strong increase in plasma calcitonin gene-related peptide (CGRP) concentration and negative correlation with platelet serotonin release. Pain 106:461-470.

Lassen LH, Haderslev PA, Jacobsen VB, Iversen HK, Sperling B, Olesen J (2002) CGRP may play a causative role in migraine. Cephalalgia 22:54-61.

Levy D, Burstein R, Strassman AM (2005) Calcitonin gene-related peptide does not excite or sensitize meningeal nociceptors: implications for the pathophysiology of migraine. Ann Neurol 58:698-705.

Ma W, Chabot JG, Powell KJ, Jhamandas K, Dickerson IM, Quirion R (2003) Localization and modulation of calcitonin gene-related peptide-receptor component protein-immunoreactive cells in the rat central and peripheral nervous systems. Neuroscience 120:677-694.

Matsuka Y, Neubert JK, Maidment NT, Spigelman I (2001) Concurrent release of ATP and substance $\mathrm{P}$ within guinea pig trigeminal ganglia in vivo. Brain Res 915:248-255.

McLatchie LM, Fraser NJ, Main MJ, Wise A, Brown J, Thompson N, Solari R,
Lee MG, Foord SM (1998) RAMPs regulate the transport and ligand specificity of the calcitonin-receptor-like receptor. Nature 393:333-339.

Moreno MJ, Cohen Z, Stanimirovic DB, Hamel E (1999) Functional calcitonin gene-related peptide type 1 and adrenomedullin receptors in human trigeminal ganglia, brain vessels, and cerebromicrovascular or astroglial cells in culture. J Cereb Blood Flow Metab 19:1270-1278.

Moreno MJ, Abounader R, Hebert E, Doods H, Hamel E (2002) Efficacy of the non-peptide CGRP receptor antagonist BIBN4096BS in blocking CGRP-induced dilations in human and bovine cerebral arteries: potential implications in acute migraine treatment. Neuropharmacology 42:568-576.

Muff R, Buhlmann N, Fischer JA, Born W (1999) An amylin receptor is revealed following co-transfection of a calcitonin receptor with receptor activity modifying proteins-1 or -3. Endocrinology 140:2924-2927.

Natura G, von Banchet GS, Schaible HG (2005) Calcitonin gene-related peptide enhances TTX-resistant sodium currents in cultured dorsal root ganglion neurons from adult rats. Pain 116:194-204.

Okabe M, Ikawa M, Kominami K, Nakanishi T, Nishimune Y (1997) 'Green mice' as a source of ubiquitous green cells. FEBS Lett 407:313-319.

Olesen J, Diener HC, Husstedt IW, Goadsby PJ, Hall D, Meier U, Pollentier S, Lesko LM (2004) Calcitonin gene-related peptide receptor antagonist BIBN 4096 BS for the acute treatment of migraine. N Engl J Med 350:1104-1110.

Oliver KR, Wainwright A, Edvinsson L, Pickard JD, Hill RG (2002) Immunohistochemical localization of calcitonin receptor-like receptor and receptor activity-modifying proteins in the human cerebral vasculature. J Cereb Blood Flow Metab 22:620-629.

Poyner DR, Sexton PM, Marshall I, Smith DM, Quirion R, Born W, Muff R, Fischer JA, Foord SM (2002) International Union of Pharmacology. XXXII. The mammalian calcitonin gene-related peptides, adrenomedullin, amylin, and calcitonin receptors. Pharmacol Rev 54:233-246.

Segond von Banchet G, Pastor A, Biskup C, Schlegel C, Benndorf K, Schaible HG (2002) Localization of functional calcitonin gene-related peptide binding sites in a subpopulation of cultured dorsal root ganglion neurons. Neuroscience 110:131-145.

Storer RJ, Akerman S, Goadsby PJ (2004) Calcitonin gene-related peptide (CGRP) modulates nociceptive trigeminovascular transmission in the cat. Br J Pharmacol 142:1171-1181.

Strassman AM, Levy D (2006) Response properties of dural nociceptors in relation to headache. J Neurophysiol 95:1298-1306.

Tam CW, Husmann K, Clark NC, Clark JE, Lazar Z, Ittner LM, Gotz J, Douglas G, Grant AD, Sugden D, Poston L, Poston R, McFadzean I, Marber MS, Fischer JA, Born W, Brain SD (2006) Enhanced vascular responses to adrenomedullin in mice overexpressing receptor-activitymodifying protein 2 . Circ Res 98:262-270.

Theoharides TC, Donelan J, Kandere-Grzybowska K, Konstantinidou A (2005) The role of mast cells in migraine pathophysiology. Brain Res Brain Res Rev 49:65-76.

Tronche F, Kellendonk C, Kretz O, Gass P, Anlag K, Orban PC, Bock R, Klein R, Schutz G (1999) Disruption of the glucocorticoid receptor gene in the nervous system results in reduced anxiety. Nat Genet 23:99-103.

Ulrich-Lai YM, Flores CM, Harding-Rose CA, Goodis HE, Hargreaves KM (2001) Capsaicin-evoked release of immunoreactive calcitonin generelated peptide from rat trigeminal ganglion: evidence for intraganglionic neurotransmission. Pain 91:219-226.

Waeber C, Moskowitz MA (2005) Migraine as an inflammatory disorder. Neurology 64:S9-15.

Zhang Z, Dickerson IM, Russo AF (2006) Calcitonin gene-related peptide receptor activation by receptor activity-modifying protein-1 gene transfer to vascular smooth muscle cells. Endocrinology 147:1932-1940. 